\title{
Assessment of the Flow at the Chatara on Koshi River Basin using Semi Distributed Model
}

\author{
Narayan Prasad Gautam \\ Pashchimanchal Campus, Institute of engineering, Tribhuvan University, Pokhara, Nepal \\ Corresponding author: npgautam@wrc.edu.np
}

Received: Feb. 20, $2016 \quad$ Revised: July 9, $2016 \quad$ Accepted: Aug. 20, 2016

\begin{abstract}
Hydrological modeling is a physical phenomenon to incorporate rainfall-runoff process in watershed area at particular point and analysis the behaviors of the flow through outlet. There are various types of models such as black box, conceptual and physical based model depends upon the availability of required data, parameters and description of the physical process. Semi distributed model is a conceptual and physical based model which has been developed to bridge the gap between the lumped and distributed model. It have more advantages than other models with respect to time of calculation, less number of parameters, comparatively low calibration needs and have high efficiency of model. The model performance may be achieved upon the qualitative and quantitative available rainfall data, land use data and size of the watershed. In this study, Koshi river basin was taken for the study area. Kinematic wave method was used for overland routing and Muskingum cunge method was applied for channel routing to describe the discharge on Saptakoshi river and peak flow attenuation and dispersion observed in the direct runoff hydrograph. From this study result, Annual runoff, Peak flow and time of peak at the outlet are similar to the observed flow in calibration and verification period using trapezoidal channel. The nash efficiency obtained from the semi distributed model with kinematic wave method is more than $90 \%$ in verification periods and nearly $90 \%$ in calibration periods Hence Hydrological modeling is a powerful technique in the planning and development of integrated approach for management of water resources
\end{abstract}

Key words: hydrograph, hydrological modeling, semi distributed model, calibration, Kinematic wave, Muskingum cunge.

\section{Introduction}

Hydrologic models have been developed to simulate specially rainfall-runoffs process in watershed area at any point and behaviors of flow through them [8]. The aim of any watershed rainfall-runoff model is to provide a hydrograph showing the variation of volume flow rate of direct runoff over time at a particular point of interest, usually taken as the watershed outlet. Analysis of rainfall runoff process in watershed is very essential because of it has a great direct impact on life of more people and for development of the structures. The success of development 
projects (dam, bridge and culverts) depends on the availability of accurate information describing the volume of runoff that a particular watershed will generate in response to a certain depth of precipitation falling on the basin. Simulated output as a hydrograph through the models are utilized directly or in conjunction with other software for the study as well as analysis of urban drainage, flood forecasting, flood plain regulation future urban impact, system operation and flood damage reduction

All the hydrologic models of catchment or basin can be classified into the three broad types as black box models, conceptual models and physically based models with respect to the use of the observational data and the description of the physical processes. The conceptual and physically based models can be categorized as lumped, semi-distributed and distributed model. Lumped models treat the catchment as one or more homogeneous land segments where the inputs are averaged, in other words, lumped taking little or no account of spatial variability of watershed characteristics. Distributed models explicitly represent the spatial variability by dividing the catchment into grids and modeling each grid cell individually. Semi distributed models are the models that falls between these two models that effectively bridge the gap between the lumped models and the fully distributed, physically based models. They utilize conceptual relationships for hydrological processes that are applied to several relatively homogeneous sub-areas of the catchment [14]. A major issue in hydrologic modeling is the model performs optimally and affects the simulation result at the end of the watershed. The simulation result will be qualitatively as well as quantitatively depends on the available of efficient and adequate rainfall data and size of the watershed. The optimal spatial scale should be adapted to the modeling objectives for determination of the dominant hydrological processes. The size of sub basin affects the landscape heterogeneity too.

Hydrological simulation could be performed using lumped to physically distributed hydrological models. Since lumped model has no physical meanings and distributed model is difficult and quite sophisticated as it requires large number of parameters, semi-distributed model with lesser set of available data is commonly used as it requires less number of parameters. Semi-distributed hydrological models generally have the advantages of short calculation time, comparative low calibration needs and high model efficiency. Analysis of hydrological behaviors of sub basin of catchment is needed to assessment of flow at the end of watershed. The main objective of this study is to assess hydrological behavior of sub-division of basin and to examine hydrograph at basin's outlet predicted by the semi- distributed model.

\section{Theories and Model Formulation}

This semi-distributed model is a conceptual model of basin response. This model represents a basin as an open channel (a very wide, open channel), with inflow to the channel equal to the excess precipitation. Then it solves the equations that simulate unsteady shallow water flow in an open channel to compute the watershed runoff hydrograph [13]. The kinematic wave overland flow model signifies performance of overland flow on the plane surfaces; it is used to simulate actions of flow in the watershed channels. 
Overland flow is modeled using an explicit finite difference solution of the kinematic wave approximation to the Saint - Venant equation [10]. Models are based on the solution of the SaintVenant equations; partial differential equations of momentum and continuity that describe the behavior of one-dimensional unsteady flow in an open channel. In complete form, the SaintVenant equations are as follows:

Continuity: $\frac{\partial Q}{\partial x}+\frac{\partial A}{\partial t}=0$

Momentum: $\frac{\partial Q}{\partial x}+\frac{\partial\left(B Q^{2} / A\right)}{\partial x}+g A\left(\frac{\partial h}{\partial x}+S_{f+} S_{e}\right)-B q v_{x}+W_{f} B=q$

(Source: Chow et al. 1988)

One-dimensional distributed flow routing models such as the dynamic wave model, the diffusion wave model and the kinematic wave model are generated by simplifying the momentum equation by neglecting various terms. The dynamic wave is the most complete of these models. For this case, only the losses due to the wind shear force component and the drag force from eddies in the flow are neglected in the momentum equation. The simplified version of the momentum equation for this model is presented below with each term labeled.

$$
\begin{aligned}
& \frac{1}{A} \frac{\partial Q}{\partial t}+\frac{1}{A} \frac{\partial}{\partial x} \frac{\left(Q^{2} / A\right)}{g}+g \frac{\partial y}{\partial x}-g\left(S_{0}-S_{f}\right)=0 \\
& \text { where, } \quad \frac{1}{A} \frac{\partial Q}{\partial t}=\text { Local Acceleration }
\end{aligned}
$$

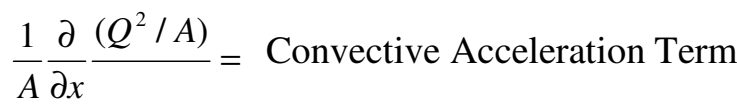

$$
\begin{aligned}
& g \frac{\partial y}{\partial x}=\text { Pressure Force Term } \\
& g S_{0}=\text { Gravity Force Term } \\
& g S_{f}=\text { Fricition Force Term }
\end{aligned}
$$

The dynamic wave model can account for acceleration, differences in pressure, and the effects of both gravity and frictional forces on the flow. The diffusion wave represents the next step down in complexity from the dynamic wave model. The simplified version of the momentum equation used in the diffusion wave model is presented below.

$$
g \frac{\partial y}{\partial x}-g\left(S_{0}-S_{f}\right)=0
$$

The diffusion wave neglects the effects of acceleration, but can still account for pressure differences as well as gravitation and frictional forces. The Kinematic Wave model is the simplest of the distributed models. The momentum equation used in this model (2.4) neglects 
both acceleration and pressure terms, describing the flow behavior in terms of gravitational and frictional forces alone.

$$
g\left(S_{0}-S_{f}\right)=0
$$

In other words this model assumes that the slope of the energy grade line is parallel to that of the channel bed $S_{0}=S_{f}$. Since flow is steady, we may approximate $Q$ using Manning's equation

$$
Q=\frac{S_{f}^{\frac{1}{2}}}{N P^{3 / 2}} A^{5 / 3}
$$

where $\mathrm{Q}=$ flow, $\mathrm{R}=$ hydraulic radius, $\mathrm{A}=$ cross-sectional area, and $\mathrm{N}=$ resistance factor that depends on the cover of the planes. Solving this equation for Area (A) gives

$$
A=\left(\frac{N P^{2 / 3}}{S_{f}{ }^{1 / 2}}\right)^{3 / 5} Q^{3 / 5}
$$

This equation may be simplified to obtain

$$
\begin{gathered}
A=\alpha Q^{\beta} \\
\alpha=\left(\frac{N P^{2 / 3}}{S_{f}^{1 / 2}}\right)^{0.6}
\end{gathered}
$$

where $\alpha$ and $\beta$ are parameters related to flow geometry and surface roughness

Substituting this expression for A into the continuity equation gives

$$
\frac{\partial Q}{\partial x}+\alpha \beta Q^{\beta-1} \frac{\partial Q}{\partial t}=q
$$

Equation 2.9 may be solved for Q at any point along the reach length at any time, using either analytical or numerical techniques.

Stream Channel Routing: The watershed of study area should be divided into smaller and more homogeneous sub division for investigation of large and non homogenous watershed. The storm hydrograph for each sub-basin is then routed through the channel and combined with individual sub-basin hydrographs to develop a storm hydrograph for the entire watershed [15]. Channel properties are extracted with the help of Geographical Information System (GIS) tool with the extension HEC Geo-RAS. Manning's roughness coefficient (n) is taken from the soil map.

\section{Study Area for Simulation}

The Koshi River basin is the biggest river of Nepal which lies in the Eastern development of Nepal between latitudes $27^{\circ} 06^{\prime} 23^{\prime \prime}$ to $28^{\circ} 09^{\prime} 50^{\prime}$ N $\mathrm{N}$ and longitudes $88^{\circ} 22^{\prime} 36^{\prime \prime}$ to $88^{\circ} 23^{\prime} 37^{\prime \prime}$. The total Catchment area is approximately $60,000 \mathrm{sq} \mathrm{Km}$. The catchment area estimated for an outlet 
at Chatara is $25923 \mathrm{sq} \mathrm{km}$ which is about $18 \%$ of total area of the Country. The highest elevation in this basin is $8848 \mathrm{~m}$ (Mt. Everest) and the lowest elevation is $140 \mathrm{~m}$ at Chatara. The location map of the studied basin is shown in Fig. 3.1. The major tributaries forming the Saptakoshi in koshi river basin are Indrawati, Bhotekoshi, Tamakoshi, Dudhkoshi, Likhu, Arun and Tamur. Among them, three main confluences of the koshi are the Sunkoshi in West, Arun in the central region and Tamur in the Eastern part. Downstream of the confluence, the river is named as Saptakoshi whereas in the upstream it is named after the name of three major tributaries namely Sunkoshi, Arun and Tamur.

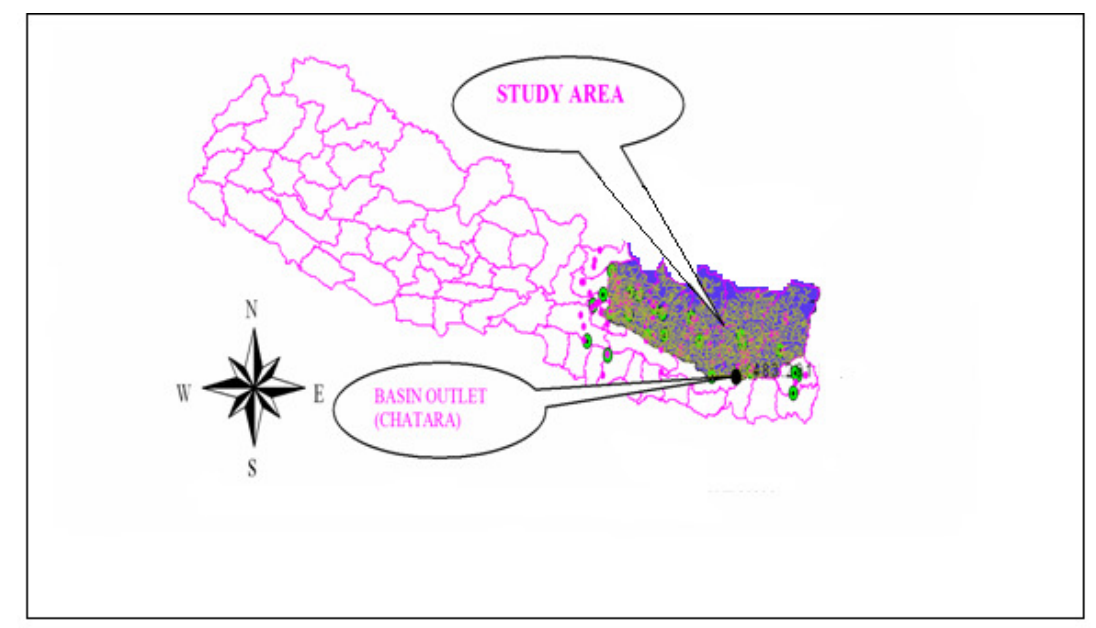

Fig. 3.1: Location Map of the study

The hydrological characteristics of the Koshi river and its tributaries are given in table 3.1

Table 3.1 Hydrological Characteristics of Koshi River and its tributaries

\begin{tabular}{|l|l|l|l|l|}
\hline River's name & Gauging station & River's length, km & $\begin{array}{c}\text { Drainage } \\
\text { area, Sq.km }\end{array}$ & \multicolumn{1}{|c|}{$\begin{array}{c}\text { Maximum } \\
\text { flood flow, cumecs }\end{array}$} \\
\hline Sunkoshi & Kampughat & 330 & 19,000 & 2,890 \\
\hline Arun & Tumlintar & 510 & 3,600 & 1,481 \\
\hline Tamor & Mulghat & 190 & 6,000 & 1,407 \\
\hline Saptakoshi & Barahkshetra & 720 & 61,000 & 6,981 \\
\hline
\end{tabular}

All these rivers are perennial in nature and some of them are snow fed river also there are altogether eleven discharge gauging stations in different river namely at Majhimtar and Mulghat in Tamur river, Uwagaon and Tudkeghat in Arun river, Rabuwaghat in Dudhkoshi, Sangutar in Likhu, Rasnalo in Khimti, Busti in Tamakoshi, Pachawarghat in Sunkoshi, Jalbire in Balephi and Chatara in Saptakoshi. Sunkoshi basin has several numbers of glacial lakes out of them some are dangerous. The river has the feature of narrow and deep gorges in the Northern part and making wide valley in the middle part including old river terraces namely Arun valley, Tumling Tar, Dudh koshi \& Ramja Tar and in the East- West trend of the river, it has wide river valley suitable for agriculture. 


\section{Tools and Data used for Simulation}

HEC-HMS (Hydrologic Engineering Centre - Hydrological Modeling System) is modeling tool to simulate the precipitation-runoff simulation. It is added the soil moisture accounting algorithm which extended the program capabilities to both event and continuous simulation applications. HMS requires basin model, Metrologic model and control specification as input parameters. HMS is a important and flexible software that permits the user to select different routing model for the subdivision as well as different routing models for the reaches. Additionally most parameters can be estimated automatically by means of optimization method included in subbasin and reach elements [17]. A GIS companion product called the Geospatial Hydrologic Modeling Extension (HEC-GeoHMS) has been developed to aid in the creation of basin models and meteorological models for use with this software [6]. In this study the soil moisture accounting algorithm of HECHMS is used for the continuous hydrologic modeling. The soil moisture accounting model is extracted from GIS database in this research paper.

HEC-GeoHMS, was used to convert the precipitation excess to overland flow and channel runoff. The predicted hydrograph was calibrated against observed one and the model parameters were manually optimized for good simulation [7]. The model framework developed in the study considered the spatial variation in the runoff response of the watershed through the use of Curve Numbers based on soil type and land use and the spatial distribution of the rainfall in the watershed by using rainfall data from a number of rain gauge stations located in different parts of the basin. The peak flow of the derived hydrograph was used as an input in hydraulic model (HEC-RAS) for producing flood maps showing inundation area extent and flood depths, thus directly linking the model to operational flood forecast [12].

It is clear that varieties of semi-distributed hydrological models were used to simulate the response of catchment to a particular input. Each semi-distributed model is developed under the catchment delineation concept. The accuracy and performance of models are related with the size of the basin. In Nepal, different semi-distributed models are used for rainfall runoff modeling like, assessment of hydropower potential, flood forecasting, and impact of forest and climate change.

\subsection{Data used for Model}

Hydro-Metrological Data: This study examines rainfall- runoff process of basin on the hydrograph at the basin's outlet by considering the model's response of two-year separate precipitation. To achieve the above specified objective it is essential to understand the hydrological processes as well as the required computer based tools for simulating the conversion of precipitation into runoff and the routing of the flood waves at downstream outlet. HydroMeteorological data of Koshi watershed was collected from Department of Hydrology and Meteorology. Meteorological data used in this study includes precipitation, maximum and minimum temperature, maximum and minimum relative humidity data of daily duration. To account for spatial and temporal variability over rainfall, inverse distance method was used. 
Soil and Vegetation Data: Vegetation and soil type play vital role in defining the land surface characteristics. Soil and land use data having resolution of $250 \mathrm{~m}$ were used. They are required mainly to estimate the parameters and to understand or visualize the runoff generation mechanism within the watershed. From the land use map, land use patterns and features within each sub-basin was identified and the soil map was used to study types of vegetation, infiltration characteristics and moisture holding capacity of soil in catchment. The soil and land use map were analyzed using GIS.

\section{Methodology}

The objective of the study is to assess the effect of sub-basin numbers in semi-distributed rainfall-runoff modeling with the help of input data including precipitation, discharge, DEM (digital elevation model), soil, land use and metrological data. Kinematic wave method is used both catchment and channel routing. To fulfill this objective, the HEC-HMS Model is used. Finally, the output is compared with the observed discharge at selected gauging of the basin [6]. The overall conceptual framework is as shown in Fig. 5.2. The conceptual frame work for overall methodology is followed by:

- GIS based processing

- Rainfall runoff modeling.

Before performing any spatial analysis of a river basin we should first prepare a three dimensional replica of the catchment. Digital elevation model (DEM) is one of such 3D model, which is prepared by generating a surface passing through the nodes of a triangular irregular network (TIN). DEM is a sampled array of elevations for a number of ground positions at regularly spaced intervals. DEM describes the elevation of any point in the study area in digital format and contains the information on drainage, crest and breaks of slopes. DEM is the primary spatial data source based on which GEOHMS extract catchments boundary, topographic variables such as basin geometry, stream networks, slope, aspect, flow direction, etc. DEM of the study area is shown in Fig. 5.1.

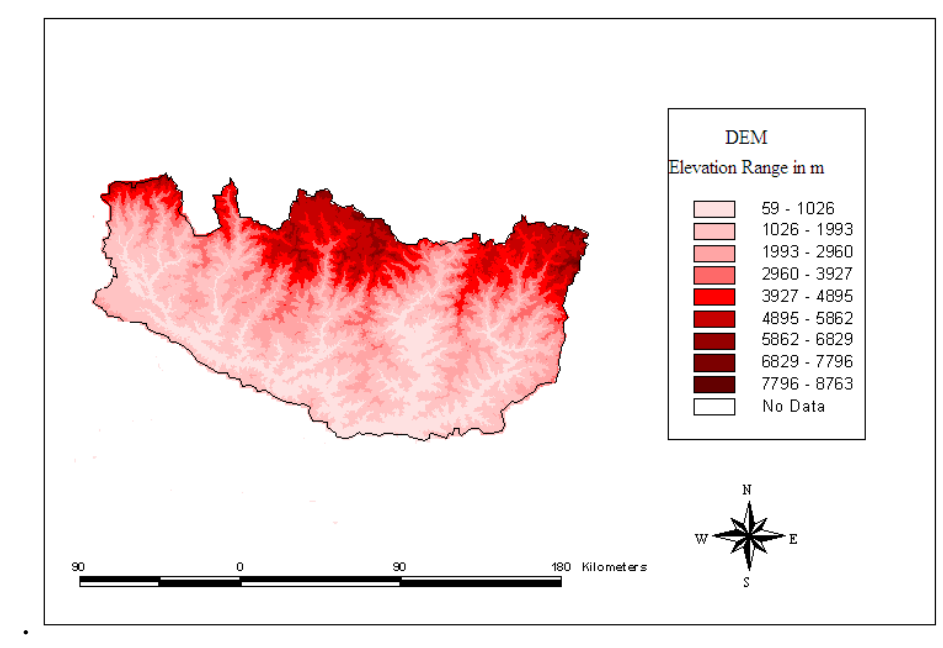

Fig. 5.1: DEM of the study area 


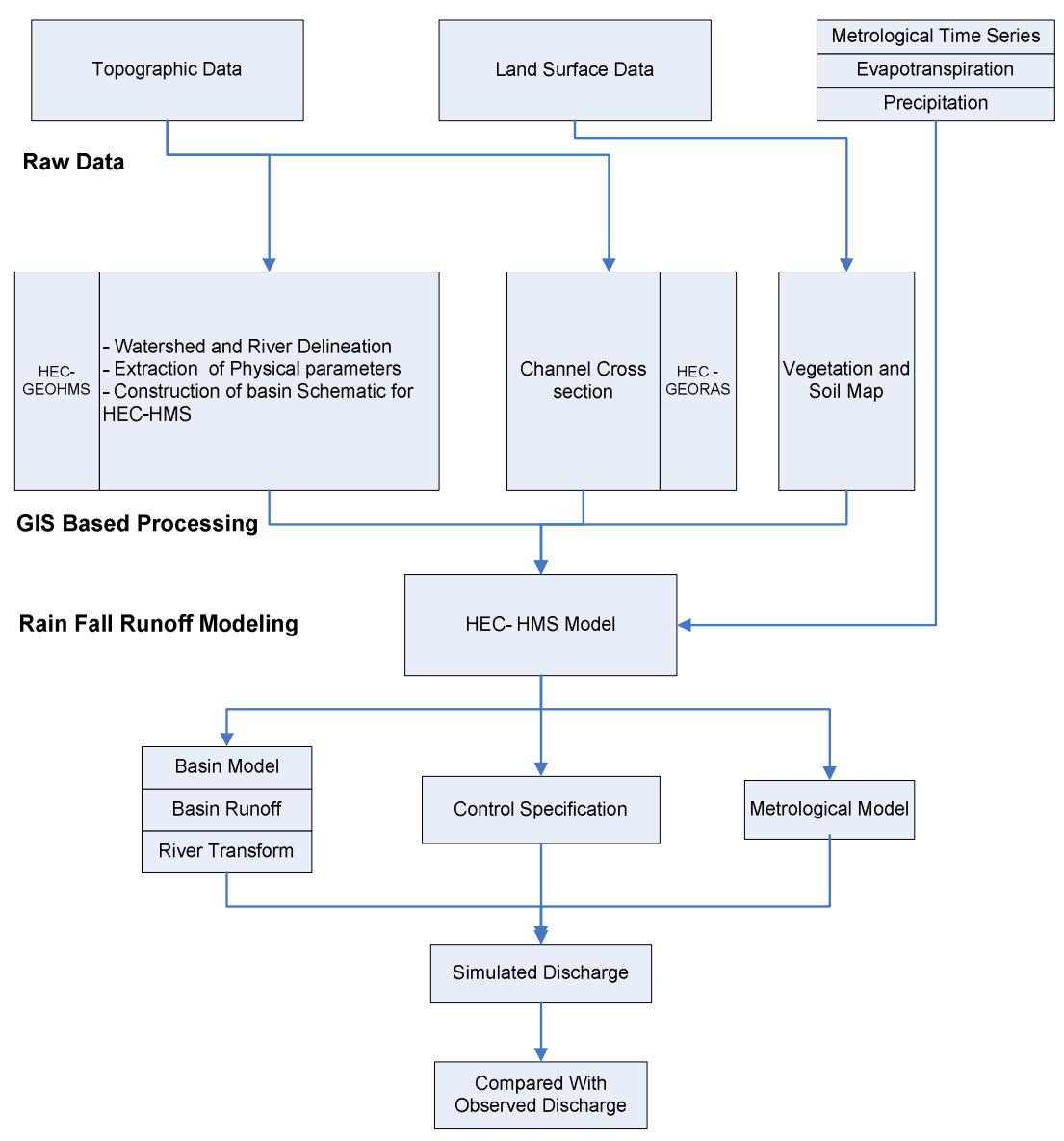

Fig. 5.2: Conceptual Frameworks

The work was made simpler by the availability of $100 \mathrm{~m}$ resolutions DEM of whole Nepal in free downloadable web site. The DEM for Koshi basin was clipped out. Stream and watershed delineation has been conducted using HEC-GeoHMS Extension.

\section{Simulation Process of the Model}

Terrain processing: Terrain processing is used to generate hydrologic parameters from Digital Elevation Model (DEM). Different processes used to generate the attribute data of river and catchment area.

Basin Processing: The basin processing menu in the HEC-GeoHMS provides the tools for extracting characteristic of stream and sub-basin. These physical parameters are river length, river slope, sub-basin area, slope stream invert profile length along the river path, Centroid elevation and location of each sub-basin, longest flow path for each sub-basin, and length along stream path from cancroids to sub-basin outlet. 


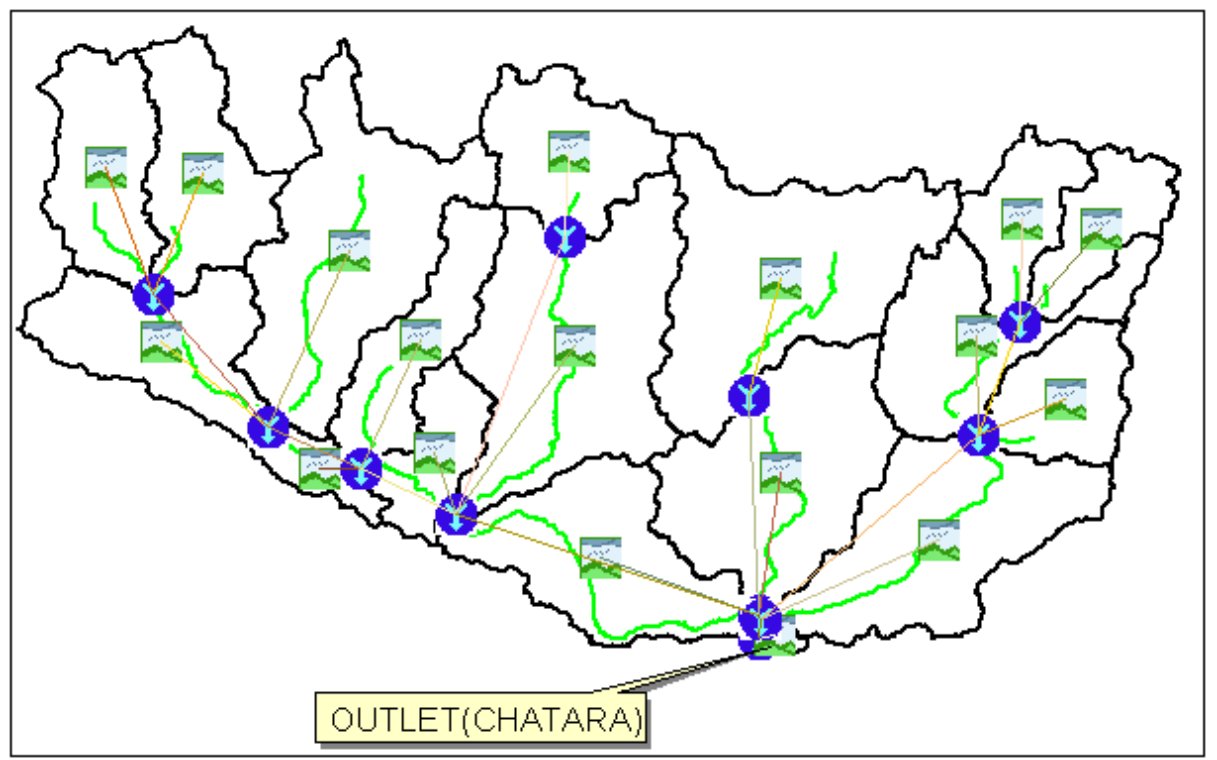

Fig. 6.1: Project view of Koshi basin

Hydrologic and Basin Parameters: Hydrologic modeling in basin model of HECHMS include overland flow and channel flow analysis. Each type of flow requires its own parameters and each has its own set of modeling methods. The ability to determine these parameters as well as the establishment of a connection between flow types in a comprehensive network is crucial to model development [11]. Some of these parameters represent physically based characteristics such as slopes, length, and areas and can be directly estimated from easily available GIS data. While surface roughness and infiltration capacity is assumed to be uniform over areas with similar landuse characteristics. Areas of land that should have similar characteristics are typically inferred from information about soils, landuse, and other GIS data.

Overland Flow parameter: The portion of rainfall remaining after abstractions becomes excess rainfall, also called direct runoff. There are various modeling methods between precipitation and runoff process and concept. The kinematic wave model is one simplest and easier method that provides a set of equations governing the amount of excess precipitation traveling over a land surface with physical parameter requirements [11].

Table 6.1 Green and Ampt parameters

\begin{tabular}{|c|c|c|c|}
\hline Sub-basin Name & Moisture Deficit & Suction head(mm) & Hydraulic conductivity(mm/hr) \\
\hline R20W20 & 0.38 & 110 & 0.45 \\
\hline R30W30 & 0.44 & 145 & 0.9 \\
\hline R40W40 & 0.34 & 25 & 0.07 \\
\hline R50W50 & 0.38 & 120 & 0.3 \\
\hline R60W60 & 0.48 & 230 & 2.1 \\
\hline
\end{tabular}




\begin{tabular}{|c|c|c|c|}
\hline R70W70 & 0.45 & 125.5 & 1.2 \\
\hline R80W80 & 0.34 & 45 & 0.4 \\
\hline R90W90 & 0.33 & 37 & 0.32 \\
\hline R100W100 & 0.4 & 38 & 0.15 \\
\hline R110W110 & 0.39 & 120 & 0.55 \\
\hline R120W120 & 0.33 & 37 & 0.32 \\
\hline R130W130 & 0.33 & 27.5 & 0.15 \\
\hline R160W160 & 0.45 & 215 & 1.25 \\
\hline R190W190 & 0.34 & 25 & 0.07 \\
\hline
\end{tabular}

Table 6.2: Adopted Overland flow Roughness coefficient Value. The overland flow plane Values estimated using GIS.

\begin{tabular}{|c|c|c|c|c|c|c|c|c|c|}
\hline \multirow{2}{*}{$\begin{array}{l}\text { Sub-basin } \\
\text { Name }\end{array}$} & \multirow{2}{*}{$\begin{array}{l}\text { Area } \\
(\mathrm{Sq} . \mathrm{Km})\end{array}$} & \multicolumn{4}{|c|}{ Plane 1} & \multicolumn{4}{|c|}{ Plane2 } \\
\hline & & $\begin{array}{l}\text { Length } \\
(\mathrm{m})\end{array}$ & Slope & $\begin{array}{l}\text { Roug } \\
\text { hness }\end{array}$ & $\begin{array}{l}\% \\
\text { area }\end{array}$ & $\begin{array}{l}\text { Length } \\
\text { (m) }\end{array}$ & Slope & $\begin{array}{l}\text { Roug } \\
\text { hness }\end{array}$ & $\begin{array}{l}\% \\
\text { area }\end{array}$ \\
\hline R20W20 & 1229.66 & 14748.5 & 0.115 & 0.5 & 65 & 7948.6 & 0.198 & 0.5 & 35 \\
\hline R30W30 & 2685.7 & 21692.82 & 0.101 & 0.57 & 52 & 23496 & 0.143 & 0.57 & 48 \\
\hline R40W40 & 4076.2 & 20554 & 0.128 & 0.35 & 36 & 26320 & 0.106 & 0.35 & 64 \\
\hline R50W50 & 1314.96 & 5053 & 0.267 & 0.51 & 32 & 17349 & 0.187 & 0.51 & 68 \\
\hline R60W60 & 2349.17 & 23054 & 0.086 & 0.52 & 47 & 25800 & 0.088 & 0.52 & 53 \\
\hline R70W70 & 2963.26 & 26085 & 0.125 & 0.65 & 71 & 7497.2 & 0.227 & 0.65 & 29 \\
\hline R80W80 & 1401.74 & 32963.86 & 0.05 & 0.57 & 65 & 22060 & 0.09 & 0.57 & 35 \\
\hline R90W90 & 1051.13 & 9649.8 & 0.144 & 0.7 & 50 & 11160.7 & 0.203 & 0.7 & 50 \\
\hline R100W100 & 2219.26 & 13961.25 & 0.143 & 0.7 & 42 & 12281 & 0.11 & 0.7 & 58 \\
\hline R110W110 & 890.81 & 8122 & 0.27 & 0.6 & 42 & 18693 & 0.15 & 0.6 & 58 \\
\hline R120W120 & 702.21 & 10503.71 & 0.113 & 0.7 & 29 & 33055.7 & 0.093 & 0.7 & 71 \\
\hline R130W130 & 384.02 & 7990 & 0.12 & 0.53 & 77 & 6250 & 0.091 & 0.53 & 23 \\
\hline R160W160 & 1902.95 & 12835.6 & 0.127 & 0.7 & 34 & 17253.5 & 0.13 & 0.7 & 66 \\
\hline R190W190 & 2788.69 & 28869.3 & 0.132 & 0.5 & 53 & 17424.7 & 0.195 & 0.5 & 47 \\
\hline
\end{tabular}

Stream Reach Parameters: Flow in modeling within river channel and flood banks is widely essential to assess the flow on outlet, besides the movement of excess precipitation over the land surface. The process of hydrologic routing includes the combination of upstream flow and watershed runoff to predict the rate at which water will flow through a given point in the stream [11]. While there are many methods of predicting stream routing in HEC-HMS, the model used in this study is the Kinematic wave method. 
194 Assessment of the flow at the Chatara on Koshi river basin using semi distributed model

Table 6.3 Stream reaches parameter values of the Sub-basin

\begin{tabular}{|c|c|c|c|c|c|c|}
\hline Element Name & $\begin{array}{c}\text { Length } \\
(\mathrm{km})\end{array}$ & Slope & Manning's n & Shape & $\begin{array}{c}\text { Bottom } \\
\text { Width }(\mathrm{m})\end{array}$ & Side Slope \\
\hline R60 & 71.374 & 0.0028 & 0.045 & Trapezoid & 95 & 2.38 \\
\hline R80 & 51.375 & 0.0023 & 0.095 & Trapezoid & 70 & 3.18 \\
\hline R100 & 99.150 & 0.0042 & 0.095 & Trapezoid & 92.5 & 1.78 \\
\hline R120 & 33.202 & 0.0022 & 0.095 & Trapezoid & 40 & 2.765 \\
\hline R130 & 30.161 & 0.0025 & 0.058 & Trapezoid & 120 & 3.09 \\
\hline R160 & 110.82 & 0.0019 & 0.065 & Trapezoid & 98 & 2.79 \\
\hline R170 & 0.991 & 0.001 & 0.045 & Trapezoid & 75 & 3.69 \\
\hline R180 & 6.299 & 0.001 & 0.045 & Trapezoid & 96 & 2.35 \\
\hline
\end{tabular}

Channel Physical parameter: Channel geometry is one of the important parameter in rainfall runoff simulation. Using the extension GeoRAS the attribute of the channel is extracted from the TIN (Triangulated irregular network) model

\section{Simulation Results and Discussion}

This study examines the assessment of the flow hydrograph by taking into account of the certain number of sub basin at the basin's outlet by considering the model's response of two-year separate precipitation. The basin is divided into number of sub-basin on the basis of river networks, landuse, and soil type. Runoff from each of the sub basin is estimated and routed using

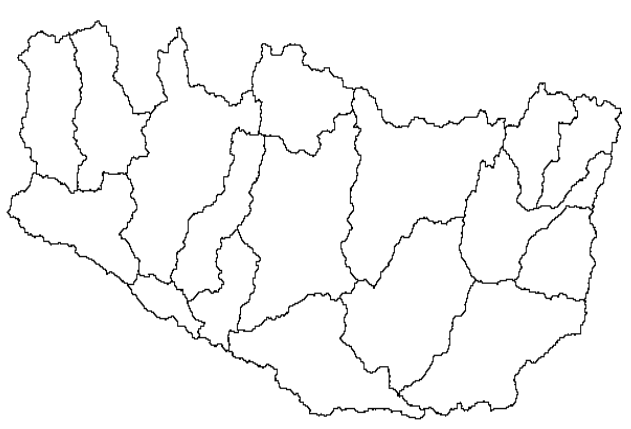
kinematic wave method to calculate total flow at the outlet of basin.

\subsection{Comparison of Observed and Simulated Hydrographs at Calibration of Model}

The model is calibrated using 1995 daily rainfall runoff data. Manual and automatic calibration techniques are applied to estimate values of parameters. In these simulation run, the whole study area is divided into 17 subdivisions. After subdivision, the sub basins are assumed to be homogenous and the model parameters are assigned according to the type of soil and land use pattern within sub-basin. The shape of simulated hydrograph from model run and observed hydrograph at outlet of basin and their scatter are shown in Fig. 7.1 and 7.2. This result shows that the low flows and peak flow are well matched with observed but total runoff volume is overestimated. Total volume deviation and Nash efficiency for 17 subdivision are $+6.9 \%$ and $86.8 \%$. 


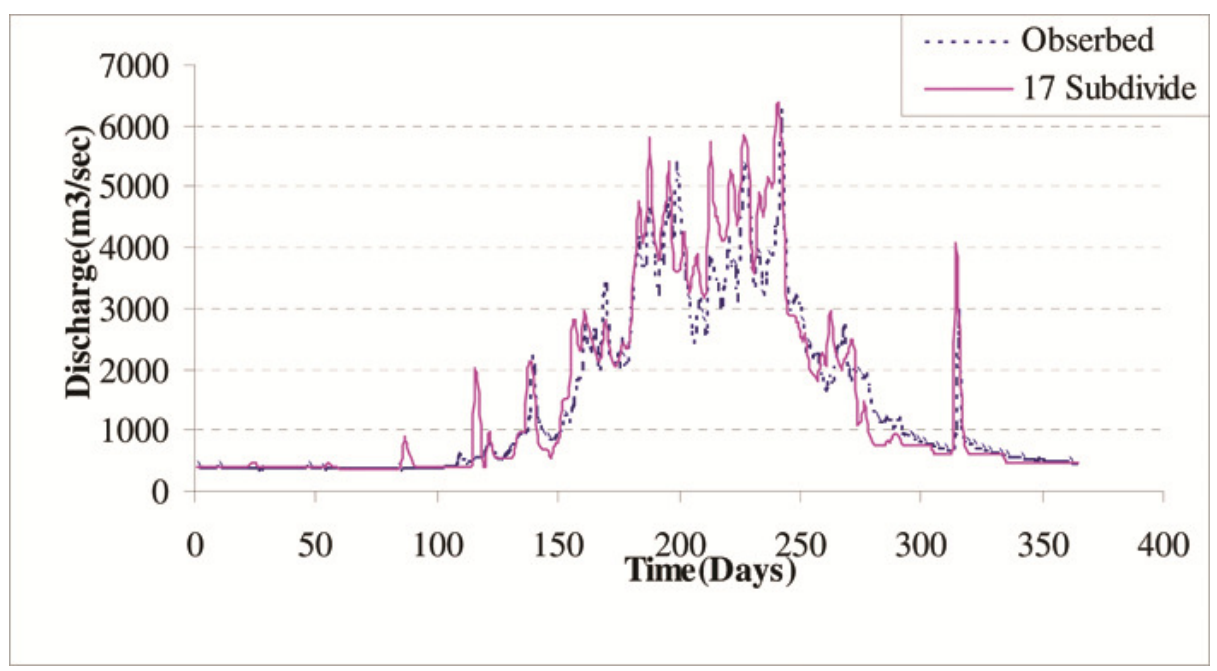

Fig. 7.1: Basin hydrograph generated in calibration period (1995)

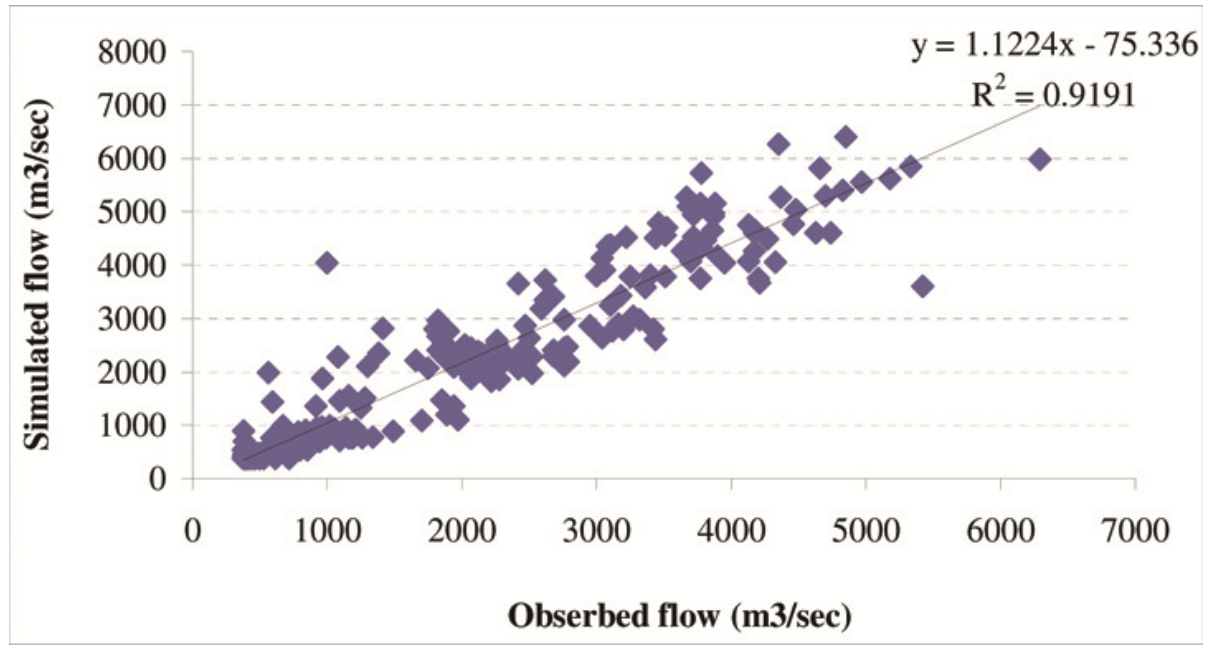

Fig. 7.2: Scatter Plot in Calibration Period (1995)

\subsection{Comparison of Observed and Simulated Hydrographs at Verification of Model}

The model is again run for one year's daily rainfall runoff data using calibrated parameters. In model verification, the runoff is simulated using 1994 daily rainfall-runoff data. The procedure applied in model verification is same as that applied in model calibration. Fig 7.3 shows the observed and simulated hydrographs at verification of model. The shape of simulated hydrograph from model run and observed hydrograph at outlet of basin and their scatter are similar to calibration model. This result shows that the low flows and peak flow are well matched with observed but total runoff volume is slightly overestimated. The time to peak is one day earlier than observed time. Total volume deviation and Nash efficiency for 17 subdivision are $+2 \%$ and $90.54 \%$. 
196 Assessment of the flow at the Chatara on Koshi river basin using semi distributed model

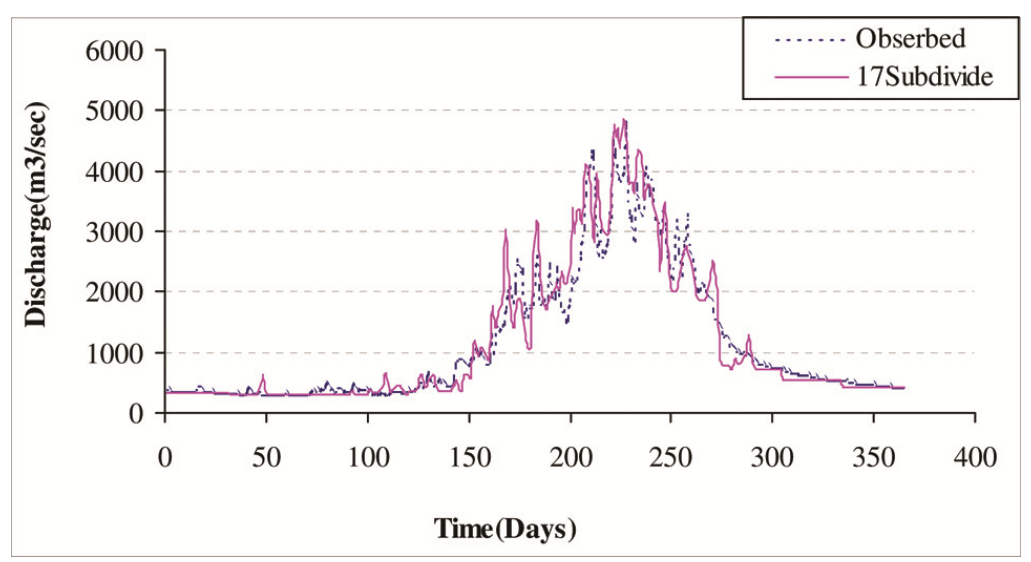

Fig. 7.3: Basin hydrograph generated in varification period (1994)

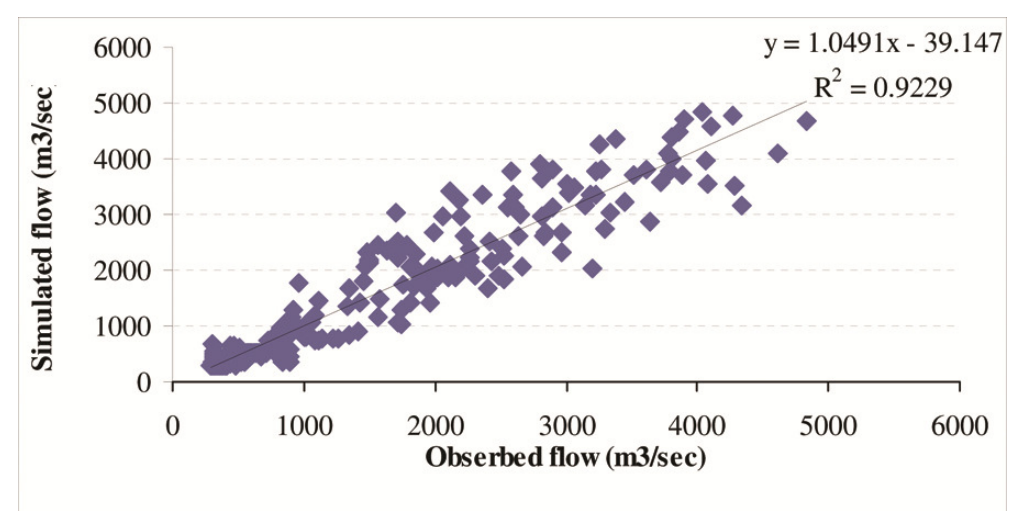

Fig. 7.4: Scatter plot for verification period (1994)

\subsection{Effect of numbers of subdivision on average stream flow discharge}

The Fig. 7.1 and 7.3 shows the simulated average annual stream flow discharges that occurred at the outlet of basin during calibration and verification period. The average stream flows during calibration and verification periods are presented in table 7.1.

Table: 7.1 Average stream flow during calibration and verification of model

\begin{tabular}{|c|c|c|c|c|}
\hline $\begin{array}{c}\text { Number of } \\
\text { Subdivisions }\end{array}$ & $\begin{array}{c}\text { Observed average } \\
\text { flow } \mathrm{m}^{3} / \mathrm{sec} \\
(1995)\end{array}$ & $\begin{array}{c}\text { Simulated average } \\
\text { flow } \mathrm{m}^{3} / \mathrm{sec} \\
(1995)\end{array}$ & $\begin{array}{c}\text { Observed average } \\
\text { flow } \mathrm{m}^{3} / \mathrm{sec} \\
(1994)\end{array}$ & $\begin{array}{c}\text { Simulated average } \\
\text { flow } \mathrm{m}^{3} / \mathrm{sec} \\
(1994)\end{array}$ \\
\hline 17 & 1465.91 & 1570 & 1135.54 & 1164.77 \\
\hline
\end{tabular}

\subsection{Effect of numbers of subdivision on Peak Discharge and Total run off}

The Fig. 7.1 and 7.3 shows the simulated peak discharges that occur at the outlet of watershed for 1994 and 1995 years. The peak outflow discharge (Qp) and total runoff volume are presented in table 7.2 and 7.3 . 
Table: 7.2 Peak flow during calibration and verification of model

\begin{tabular}{|c|c|c|c|c|}
\hline $\begin{array}{c}\text { Number of } \\
\text { Subdivisions }\end{array}$ & $\begin{array}{c}\text { Observed Peak } \\
\text { flow } \mathrm{m}^{3} / \mathrm{sec} \\
(1995)\end{array}$ & $\begin{array}{c}\text { Simulated peak } \\
\text { flow } \mathrm{m}^{3} / \mathrm{sec} \\
(1995)\end{array}$ & $\begin{array}{c}\text { Observed peak } \\
\text { flow } \mathrm{m}^{3} / \mathrm{sec} \\
(1994)\end{array}$ & $\begin{array}{c}\text { Simulated peak } \\
\text { flow } \mathrm{m}^{3} / \mathrm{sec} \\
(1994)\end{array}$ \\
\hline 17 & 6465.91 & 6399,8 & 4135.54 & 4849.5 \\
\hline
\end{tabular}

Table: 7.3 Total runoff volumes during calibration and verification of model

\begin{tabular}{|c|c|c|c|c|}
\hline $\begin{array}{c}\text { Number of } \\
\text { Subdivisions }\end{array}$ & $\begin{array}{c}\text { Observed volume } \\
\left(10^{7} \mathrm{~m}^{3}\right) \\
1995\end{array}$ & $\begin{array}{c}\text { Simulated } \\
\text { volume } \\
\left(10^{7} \mathrm{~m}^{3}\right) \\
1995\end{array}$ & $\begin{array}{c}\text { Observed volume } \\
\left(10^{7} \mathrm{~m}^{3}\right) \\
1994\end{array}$ & $\begin{array}{c}\text { Simulated volume } \\
\left(10^{7} \mathrm{~m}^{3}\right) \\
1994\end{array}$ \\
\hline 17 & 4611 & 4936.36 & 3609 & 3669.99 \\
\hline
\end{tabular}

Time of peak outflow is shifted slightly to the right

Table: 7.4 Time to peak flow with respect to number of subdivision

\begin{tabular}{|c|c|c|c|c|}
\hline $\begin{array}{c}\text { Number of } \\
\text { Subdivisions }\end{array}$ & $\begin{array}{c}\text { Observed Peak } \\
\text { time in day } \\
(1995)\end{array}$ & $\begin{array}{c}\text { Observed Peak } \\
\text { time in day } \\
(1995)\end{array}$ & $\begin{array}{c}\text { Observed Peak } \\
\text { time in day } \\
(1994)\end{array}$ & $\begin{array}{c}\text { Observed Peak } \\
\text { time in day } \\
(1994)\end{array}$ \\
\hline 17 & $30^{\text {th }}$ August & $29^{\text {th }}$ august & $14^{\text {th }}$ august & $13^{\text {th }}$ augest \\
\hline
\end{tabular}

\subsection{Model Performance}

Model efficiency and $\mathrm{R}^{2}$ value is more accurate in verification than calibration period. The model efficiency and $\mathrm{R}^{2}$ value with respect to number of subdivision are presented in table 7.5.

Table: 7.5 Model efficiency and $\mathrm{R}^{2}$ value

\begin{tabular}{|c|c|c|c|c|}
\hline \multirow{2}{*}{$\begin{array}{c}\text { Number of } \\
\text { Sub-division }\end{array}$} & \multicolumn{2}{|l|}{1995} & \multicolumn{2}{|l|}{1994} \\
\hline & Nash Efficiency in \% & $\mathrm{R}^{2}$ values & Nash Efficiency in $\%$ & $\mathrm{R}^{2}$ values \\
\hline 17 & 86.8 & 0.919 & 90.54 & 0.922 \\
\hline
\end{tabular}

\section{Conclusion and Recommendation}

From the simulation results, hydrological analysis depends on the basin characteristics, including topography, soil and land use data. Model's accuracy largely depends upon availability of the extensive amount of data, accuracy of the available data and quality of data. This variation is due to the sensitivity of overland slope, slope length, channeling slope and drainage density. Changes in these parameters cause changes in simulation results. The analysis was done based on Kinematic wave method, however it can't describe the effect of reach storage, instead are 
manifested in the peak flow attenuation and dispersion observed in the direct runoff hydrograph. Hence it is recommended to use Muskingumkung method, a distributed runoff model that can describe hydrograph diffusion along with diffusion during routing process, which is obviously realistic. The efficiency of the model in this watershed obtained high performance nearly $90 \%$ from the semi distributed model in this study. Hence this type of model may be advantageous in the planning and development of integrated approach for management of water resources in similar size of watershed in case of having limited available parameters and time.

\section{References}

[1] Abu-Rumman and Ghaida A (2007), Characterization of the Hydrological Changes of Jordan River Side Wadis Tributaries Using Remote Sensing and GIS, University of Jordan, PhD Thesis.

[2] C-M Wu (2005), Simulating Runoff Using the Method of Characteristics with Unsteady Rainfall Events. Journal of Mechanics, 21(3): 171-178.

[3] Castellano M (2004), Modeling of the monthly and daily behavior of the runoff of the Xallas river using Box-Jenkins and neural networks methods. Journal of Hydrology, 296(1-4):38-58.

[4] Du J, Li Q, Hanyi R, Tianhui Z, Dapeng Z, Youpeng X and C-Y Xu (2012), Assessing the effects of urbanization on annual runoff and flood events using an integrated hydrological modeling system for Qinhuai River basin, China. Journal of Hydrology, 127-139.

[5] Fleming M and Vincent N (2004), Continuous Hydrologic Modeling Study with the Hydrologic Modeling System. Journal of Hydrologic Engineering, 10.1061/(ASCE)10840699 9:3(175): 175-183.

[6] Gautam NP (2014), Flow routing with Semi-distributed hydrological model HEC- HMS in case of Narayani River Basin. Journal of the Institute of Engineering, 10(1): 45-58.

[7] http://spie.org/ERS/conferencedetails/remote-sensing-for-agriculture-ecosystems-andhydrology

[8] http://vuir.vu.edu.au/219/1/02whole.pdf

[9] http://www.azwater.gov/azdwr/SurfaceWater/FloodManagement/documents/ADWR_Engineer ing_Analysis_Fluvial_Systems.pdf

[10] http://www.cct.edu.np/uploads/result/flood\%20hazard.pdf

[11] http://www.crwr.utexas.edu/gis/gishydro01/library/dugger/proj.pdf

[12] http://www.crwr.utexas.edu/gis/gishyd98/library/dugger/proj.pdf

[13] http://www.hec.usace.army.mil/SOFTWARE/hec- hms / documentation / CPD-74 B_2000 Mar.pdf

[14] http://www.icsuscope.org/downloadpubs/scope51/chapter02.html

[15] http://www.washoecounty.us/repository/files/7/tmrdm_final_043009.pdf

[16] Magar RB (2011), Intermittent reservoir daily-inflow prediction using lumped and distributed data multi-linear regression models. Journal of Earth System Science, 120(6): 1067-1084.

[17] Olivera F (2001), Extracting Hydrologic Information from Spatial Data for HMS Modeling. Journal of Hydrologic Engineering, 10.1061/(ASCE)1084-06996, 6(524): 524-530. 